river that runs where the dusky horizon shuts down on our uncertain and blinding vision. Pioneers they are, prospecting over there where thought and act preceded them, looking for that ideal which they could not realize here.

'Tis whispered low within the heart

We hear it rise and fall,

A song of those who answer not

However we may call.

They can not be where God is not

On any sea or shore;

Whate'er betides, Thy love abides

Our God forevermore.

\title{
RESOLUTIONS COMMEMORATING THE DEATH OF MR. ALDRICH.
}

Resolutions or memorials commemorating the death of Mr. Aldrich were adopted by the following organizations:

Military Order of the Loyal Legion of the United States, Commandery of the State of Iowa.

Winfield Scott Post No. 66, Department of Iowa G. A. R.

Soldiers' Roster Board:

Board of Trustees of the State Library and Historical Department.

Octogenarian Association.

Monday Club.

The Board of Trustees of the State Library and Historical Department adopted the following resolutions:

Whereas, The Hon. Charles Aldrich has for many years bren associated with this Board as Curator of the Historical Deparinent of the Iowa State Library, in this relation afford. ing us opportinnity to know him intimately, and

Whereas, His qualities of head and heart have impressed us as of the highest order and his service to the State of the greatest worth, therefore be it

Resolved, By the Board of Trustees of the Iowa State Library that in the passing of Mr. Aldrich we have lost a loved associate and wise counselor; that in creating and fostering the Historical Department and in conserving the early history 
of the State, he has rendered a service of untold value to the present and to the future generations; and that in all the relations of life, in his social converse, in his literary and journalistic career, in his military and public service he has proved himself a man of high ideals, of indomitable purpose and of lofty achievement.

\section{H. E. Deemer, JOHN F. RIGGS.}

Committee.

The Soldiers' Roster Board adopted the following resolution of respect:

Whereas, Since the last meeting of this Board the hand of death has removed one of its members, the Hon. Charles Aldrich, Curator of the Historical Department of Iowa, who died at his home in Boone, Iowa, on the 8th day of March, 1908 , and

Whereas; The surviving members of the Board recognize the great loss we have sustained by the death of Curator Aldrich, therefore be it

Resolved, That we deplore his death That we revere his memory. That we herein express our appreciation of the great service he has rendered to the State in the long years in which he was engaged in the collection of the material for its history, and the records of the men and women who have been its history makers.

The secretary of this Board is hereby instructed to spread this resolution upon the minutes, and to transmit a copy of the same to Mrs. Thirza Louisa Aldrich, the widow of our deceased member, and the Historical Department of Iowa.

In the comprehensive "Memorial on the death of our late companion, Adjutant Charles Aldrich," read and adopted by the Military Order of the Lioyal Legion, Commandery of the State of Iowa, the following paragraphs occur:

"The people of Iowa recognize the great service he has rendered them in preserving the historical treasures of the commonwealth, and have provided a fitting place for the safe- 
keeping of those treasures he spent long years in accumulating, in the building. which stands in its dignity and beauty as an enduring monument to his memory.

"He lived an upright and honorable life. He devoted all his ability and energy to the accomplishment of lofty and noble purposes. He suffered and endured great physical pain for many years but his indomitable will and courage sustained him until his life work was done. He died in serene contentment. No higher, or more well deserved honors have been paid to any citizen of Iowa than .were rendered to our companion at the time of his death. In the beautiful cemetery near his early Iowa home he lies beside the wife of his early youth. Brave, gifted; noble soul, hail and farewell."

G. W. Crosuey,

G. A. Eberhart,

S. H. M. Byers.

Committee.

The resolutions adopted by the Monday Club are as follows :

Whereas, In the death of Curator Charles Aldrich the Mon. day Club of Des Moines has sustained a touching loss, therefore be it

Resolved, That this Club will hold in grateful remembrance the uniform kindness and courtesy of Mr. Aldrich in granting to this Club the use of a comfortable room in the State Historical Building for its fortnightly meetings.

We join with the family and all the people of the State in honoring the memory of a kindly, gracious and kingly man.

Mrs. Mary J. Coggeshald,

Mrs. L. A. Altona,

Mrs. Charies J. Luthe.

Committee. 
Copyright of Annals of Iowa is the property of State of Iowa, by \& through the State Historical Society of Iowa and its content may not be copied or emailed to multiple sites or posted to a listserv without the copyright holder's express written permission. However, users may print, download, or email articles for individual use. 